\title{
POJAVNOST PROBLEMA U PONAŠANJU DJECE U USTANOVAMA RANOG I PREDŠKOLSKOG ODGOJAI \\ OBRAZOVANJA
}

\section{PREVALENCE OF BEHAVIOUR PROBLEMS IN CHILDREN WITHIN EARLY CHILDHOOD EDUCATION AND CARE INSTITUTIONS}

\author{
MARINA PANIĆ, DEJANA BOUILLET \\ Faculty of Teacher Education, University of Zagreb, Savska cesta 77, Zagreb, Croatia, contact: marina.panic13@gmail.com \\ Primljeno/Received: 11.06.2021. \\ Prihvaćeno/Accepted: 27.10.2021. \\ Izvorni znanstveni rad/Original research article \\ UDK: 373.2:159.922.7-053.4 \\ $373.2: 159.9 .072$ \\ doi: 10.31299/hrri.57.2.5
}

Sažetak: Problemi u ponašanju djece rane i predškolske dobi povezani su s kasnijom socijalizacijom, prilagodbom na školu, školskim uspjehom i drugim obrazovnim postignućima $u$ adolescentskoj $i$ odrasloj dobi, što ukazuje na važnost pravovremenog prepoznavanja odstupanja od uobičajenog psihosocijalnog funkcioniranja i ponašanja djece. Poznato je da je za prevenciju nepovoljnih razvojnih ishoda, uključujuć razvoj problema u ponašanju, ključno razdoblje do šeste godine djetetova života. Cilj je ovog istraživanja analizirati pojavnost problema u ponašanju djece rane i predškolske dobi u Republici Hrvatskoj s obzirom na spol i razvojni status djece, na temelju procjena roditelja i odgojitelja. Procijenjeno je ponašanje 447 djece u dobi od pet $i$ šest godina u 10 hrvatskih programa ranog i predškolskog odgoja i obrazovanja. Utvrđeno je da s učestalošću manifestiranja problema u ponašanju opada njihov udio $u$ populaciji te da izražajnije probleme u ponašanju prema procjenama odgojitelja manifestira $7 \%$, a prema procjenama roditelja 9\% djece rane i predškolske dobi. Na uzorku ovog istraživanja nisu utvrđene razlike u procjenama učestalosti manifestiranja internaliziranih problema u ponašanju između dječaka i djevojčica, ali se pokazalo da odgojitelji i roditelji češće procjenjuju prisutnost eksternaliziranih problema $u$ ponašanju kod dječaka u odnosu na djevojčice. Odgojitelji $i$ roditelji procjenjuju da djeca s teškoćama u razvoju u odnosu na djecu tipičnog razvoja češće manifestiraju internalizirane probleme u ponašanju, dok razlike u procjenama učestalost $i$ manifestiranja eksternaliziranih problema s obzirom na razvojni status djece nisu utvrđene. Ovim istraživanjem

\begin{abstract}
Behavioural problems observed in early and preschool-aged children (aged 0-7) correlate with their ability to socialise and adjust to school, as well as their ability to make school-related and other educational achievements in adolescence and adulthood. This suggests that it is important to recognise the timely deviations from normal psychosocial functioning and behaviour in children. It is well known that the period up to the child's sixth year of life is crucial for the prevention of adverse developmental outcomes, including the development of behavioural problems. The aim of this study was to analyse the incidence of behavioural problems among preschool children in Croatia based on sex and their developmental status using data collected from parents and preschool teachers. This research assessed the behaviour of 447 children, aged 5-6 years, who were part of early and preschool education programs in 10 different kindergartens in Croatia. The results showed that an increase in the frequency of manifestations of behavioural problems was followed by a decrease in their participation in society. The preschool teachers estimated that $7 \%$ of the sample exhibited pronounced behavioural problems, while the parents estimated that $9 \%$ exhibited problems. There were no differences between boys and girls with respect to the estimates of the incidence of internalised behavioural problems, but preschool teachers and parents were more likely to observe externalised behavioural problems in boys than in girls. Both preschool teachers and parents estimated that children with disabilities were more likely to manifest internalised behavioural problems than those with typical development. Further research must be conducted to understand whether the
\end{abstract}


potvrđuju se mogućnosti ranog prepoznavanja problema $u$ ponašanju djece $i$ ukazuje se na relevantnost i povezanost procjena ponašanja djece od strane njihovih roditelja $i$ odgojitelja.

Ključne riječi: djeca rane i predškolske dobi, problemi u ponašanju, procjene roditelja, procjene odgojitelja

\section{UVOD}

Kada je riječ o izučavanju pojave problema u ponašanju, autori su pretežno usmjereni na populaciju djece i mladih školske dobi (npr. Klarin i Đerđa, 2014; Maglica i Đanko, 2016; Bijedić, Kuralić Čišić, Jahić i Muminović Vildić, 2019) iako formativnu ulogu u kognitivnom i socijalnom razvoju ima rano djetinjstvo (Das i sur., 2018; Bhopal i sur., 2019 i dr.). Zato je kvaliteta okruženja u ranoj i predškolskoj dobi važna za dobrobit, mentalno zdravlje, prevenciju devijantnih ponašanja i drugih individualno štetnih $i$ društveno neprihvatljivih pojava (Geddes, Frank i Haw, 2011). Kako objašnjavaju Živčić-Bećirević, Smojver-Ažić i Mišćenić: "Gotovo se svi stručnjaci u području mentalnog zdravlja, neovisno o modelu i teoriji kojoj se priklanjaju u objašnjavanju ljudskog ponašanja, slažu u tome da su rane godine izuzetno važne za kasniju prilagodbu te da su teškoće tijekom tih godina prethodnice problema prilagodbe u kasnijoj dobi" (2003: 64).

Istraživanja socijalizacijskih teškoća djece rane i predškolske dobi razmjerno su rijetka iako postojeće studije suglasno potvrđuju da od 3\% do $10 \%$ djece u ustanovama ranog i predškolskog odgoja manifestira odstupanja u ponašanju u mjeri koja prelazi okvire razvojne faze (Paulus, Backes, Sander, Weber i von Gontard, 2014; Vlah, Mirosavljević i Katić, 2018). Osobito su rijetka recentna istraživanja o pojavnosti problema u ponašanju djece rane i predškolske dobi u Hrvatskoj. Mikas (2007) je svojim istraživanjem utvrdio da u ustanovama ranog i predškolskog odgoja i obrazovanja ima 18\% djece koja manifestiraju neki oblik problema u ponašanju. Navarro, Fernández, De la Osa, Penelo i Ezpeleta (2019) navode da različite frequency of manifestation of externalised problems can differ based on a child's developmental status. These findings confirm the possibility of being able to recognise problems in a child's behaviour at an early age, as well as indicate the relevance and correlation of behavioural assessments made by parents and preschool teachers.

Keywords: early and preschool children; behavioural problems; parents' assessments; preschool teachers' assessments.

\section{INTRODUCTION}

When it comes to studying the occurrence of behavioural problems, researchers mainly focus on school-aged children and youth (e.g., Klarin \& Đerđa, 2014; Maglica \& Đanko, 2016; Bijedić, Kuralić Čišić, Jahić, \& Muminović Vildić, 2019). However, the early childhood period plays a formative role in cognitive and social development (e.g., Das et. al, 2018; Bhopal et. al, 2019). Therefore, the quality of the environment during early childhood is important for the well-being and mental health of a child; it can also prevent the occurrence of deviant behaviours and other harmful and socially unacceptable phenomena (Geddes, Frank, \& Haw, 2011). "Almost all mental health professionals, regardless of the model and theory they follow to explain human behaviour, agree that the early years are extremely important for later adjustment and that difficulties during these years are precursors to adjustment problems at a later age" (ŽivčićBećirević, Smojver-Ažić, \& Mišćenić, 2003, p. 64).

Research on difficulties related to socialisation among preschool children is relatively rare. Previous studies have unanimously confirmed that $3-10 \%$ of children in early and preschool educational institutions exhibit behavioural deviations that are beyond their developmental stage (Paulus, Backes, Sander, Weber, \& von Gontard, 2014; Vlah, Mirosavljević, $\&$ Katic, 2018). Current research on the prevalence of behavioural problems among preschool children in the Republic of Croatia is very limited. Mikas (2007) found that $18 \%$ of children in early and preschool educational institutions manifest some form of behavioural problems. Navarro, Fernández, de la Osa, Penelo, \& Ezpeleta (2019) stated that 1.9-10.5\% of three-year-old children faced different socialisa- 
socijalizacijske teškoće karakteriziraju od $1.9 \%$ do $10.5 \%$ djece u dobi od tri godine, dok McCoy i sur. (2016) smatraju da $26.2 \%$ djece u dobi od tri do četiri godine imaju teškoće u socijalno-emocionalnom razvoju.

Djeca rane i predškolske dobi najčešće ne mogu sama verbalizirati teškoću, već se ona manifestira neprilagođenim ponašanjem koje prepoznaju njima najbliže osobe. Radi se o ponašanjima koje autori nazivaju izazovnim ponašanjima (Dunlap i sur., 2006; Emerson i Einfeld, 2011), problemima u ponašanju (Mikas, 2007; Prykanowski, Martinez, Reichow, Conroy i Huang, 2018), socijalno-emocionalnim problemima (Brown i sur., 2012) i drugim terminima. Riječ je o ponašanju koje ometa ili postoji rizik od ometanja optimalnog učenja ili sudjelovanja u socijalnim interakcijama djeteta $\mathrm{s}$ drugom djecom i odraslima (Smith i Fox, 2003). Ta ponašanja odstupaju od ponašanja primjerenog i uobičajenog za dijete određene dobi, a uvjetovana su osobnošću djeteta, odgojnim, socijalnim, kulturnim ili drugim čimbenicima (Bouillet, 2019).

U ovom se radu koristi pojam problemi u ponašanju koji, sukladno Standardima za terminologiju, definiciju, kriterije i način praćenja pojave poremećaja u ponašanju djece i mladih (Koller-Trbović, Žižak i Jeđud Borić, 2011), obuhvaća sve oblike tog fenomena - od rizičnih ponašanja (nepoštivanje pravila, nezainteresiranost za vršnjake) preko teškoća (veći disciplinski prekršaji, povučenost) do poremećaja u ponašanju (nasilničko ponašanje, socijalna izoliranost). U okruženju institucionalnog odgoja i obrazovanja ta se ponašanja ogledaju u teškoćama u učenju, izgradnji primjerenih odnosa i neprimjerenim oblicima ponašanja koja nisu posljedica intelektualnih, senzornih ili drugih zdravstvenih teškoća.

Najčešća je podjela problema u ponašanju na eksternalizirane $\mathrm{i}$ internalizirane probleme (Macuka, Smojver-Ažić i Burić, 2012; Cicchetti i Toth, 2014; Macuka, 2016 i mnogi drugi). Eksternalizirani problemi odnose se na ponašanja koja predstavljaju problem osobama u djetetovu bližem okruženju, a potencijalno su opasna i ometajuća kako za okolinu tako i za samo dijete. Internalizirani problemi odnose se na pretjerano kontrolirajuća ponašanja koja su usmjerena prema samom djetetu, u obliku pretjerane plašljivosti, tion difficulties, while McCoy et al. (2016) believed that $26.2 \%$ of children aged 3-4 years exhibited difficulties in social-emotional development.

Early and preschool children are usually unable to verbalise the difficulties that they face on their own, which then tends to manifest into inappropriate behaviour that is recognised by those close to them. Researchers describe these behaviours using different terms, including challenging behaviours (Dunlap et al., 2006; Emerson \& Einfeld, 2011), behavioural problems (Mikas, 2007; Prykanowski, Martinez, Reichow, Conroy, \& Huang, 2018), as well as social-emotional problems (Brown et al., 2012). These behaviours interfere with or are at risk of interfering with optimal learning or participation in a child's social interactions with other children and adults (Smith \& Fox, 2003). Such behaviours often deviate from appropriate and common behaviours exhibited by a child of a certain age due to their personality, as well as educational, social, and cultural factors (Bouillet, 2019).

The present study uses the term "behavioural problems" which, in accordance with the Standards for Terminology, Definition, Criteria, and Monitoring of Behavioural Disorders in Children and Youth (KollerTrbović, Žižak, \& Jeđud Borić, 2011), includes all forms of this phenomenon from risky behaviours (disrespecting the rules, disinterest in peers) to difficulties (major disciplinary offences, reticence) and behavioural disorders (violent behaviour, social isolation). In the environment of institutional upbringing and education, these behaviours are reflected in learning difficulties, building appropriate relationships, as well as exhibiting inappropriate forms of behaviour that occur as a result of factors other than intellectual, sensory, or other health difficulties.

Behavioural problems can be categorised into externalised and internalised problems (Macuka, Smojver-Ažić, \& Burić, 2012; Cicchetti \& Toth, 2014; Macuka, 2016 and many others). Externalised problems refer to behaviours that pose a problem to individuals in the child's immediate environment, and are potentially dangerous and disruptive to the environment and the child. Internalised problems refer to excessively controlling behaviours that are directed towards the child itself in the form of excessive timidity, withdrawal, disinterest, and crying. Internalised behavioural problems often go unrecognised or can 
povučenosti, nezainteresiranosti, plačljivosti i sl. Internalizirani problemi u ponašanju često ostanu neprepoznati ili se ignoriraju jer su u odnosu na eksternalizirane probleme manje ometajući za druge. Ogundele (2018) upućuje na zaključke brojnih istraživanja prema kojima je prediktivna vrijednost eksternaliziranih problema u ponašanju u ranoj dobi djece za razvoj budućih poremećaja u ponašanju, u usporedbi s internaliziranim problemima, znatno viša. Smatra se da dječaci češće manifestiraju eksternalizirane probleme, dok su djevojčice sklonije internaliziranim problemima (Gritti i sur., 2014; Poulou, 2015; Velki, Kuterovac i Jagodić, 2015; Maglica, Reić Ercegovac i Ljubetić, 2020). Ove se razlike jednim dijelom mogu objasniti biološkim čimbenicima, ali i mogućim razlikama u odgoju dječaka i djevojčica. Moguće je da roditelji u odgoju djevojčica češće potiču empatičnost i poslušnost, dok su takva očekivanja od dječaka rjeđe prisutna zbog različitih očekivanja roditelja od svojih sinova i kćeri. Radi se o rodno uvjetovanom odgoju koji je duboko ukorijenjen u mnogim suvremenim kulturama, a vodi formiranju rodno uvjetovanih uloga od najranije dobi djeteta putem odgojnih poruka o prihvatljivim i neprihvatljivim obrascima ponašanja djevojčica i dječaka (Rogošić, Maskalan i Krznar, 2020).

Mnogi autori naglašavaju da su problemi u ponašanju djece rane dobi povezani s kasnijom socijalizacijom, prilagodbom na školu, školskim uspjehom i drugim obrazovnim postignućima u adolescentskoj i odrasloj dobi. Primjerice Sutherland i sur. (2018) ustanovili su veću vjerojatnost da djeca koja su imala teškoće $u$ ponašanju u ranoj dobi kasnije razviju poremećaje u ponašanju, a Nielsen i sur. (2019) ističu da problemi mentalnog zdravlja u ranom djetinjstvu povećavaju rizik od poremećaja mentalnog zdravlja u adolescenciji i odrasloj dobi. Posljedica je to okolnosti da su problemi u ponašanju u pravilu rezultat kumuliranja problema u različitim područjima života djeteta, pri čemu problemi u jednom području pridonose problemima u drugim područjima (Poulou, 2015). Tako istraživanja upućuju na visoku zastupljenost problema u ponašanju u populaciji djece s teškoćama u razvoju (Emerson i Einfeld, 2009).

Prepoznavanje odstupanja od uobičajenog psihosocijalnog funkcioniranja i ponašanja djeteta be ignored because they are less distracting than externalised problems to other individuals. Ogundele (2018) pointed out that several studies have concluded that children with externalised behavioural problems in early childhood face a significantly higher risk of future behavioural disorders than those with internalised problems. Additionally, boys are more likely to manifest externalised problems, while girls are more prone to internalised problems (Gritti et al., 2014; Poulou, 2015; Velki, Kuterovac, \& Jagodić, 2015; Maglica, Reić Ercegovac, \& Ljubetić, 2020). These differences can be partially explained by biological factors, but also by differences in the upbringing of boys and girls. Due to the different expectations of parents from their sons and daughters, empathy and obedience are more often encouraged in the upbringing of girls than boys. This gender-based upbringing is deeply rooted in many modern cultures and leads to the formation of gender-based roles from the early childhood through educational messages about acceptable and unacceptable patterns of behaviour of girls and boys (Rogošić, Maskalan \& Krznar, 2020).

Many authors have emphasised that behavioural problems in young children are associated with future socialisation skills, ability to adjust to school, as well as school-related and other educational achievements in adolescence and adulthood. For example, Sutherland et al. (2018) found that children who had behavioural difficulties at an early age were more likely to develop behavioural disorders later on in life, and Nielsen et al. (2019) pointed out that mental health problems in early childhood increase the risk of mental health disorders in adolescence and adulthood. This is due to the fact that behavioural problems are usually the result of the accumulation of problems in different areas of the child's life, with problems in one area contributing to problems in others (Poulou, 2015). In addition, several researchers have reported high rates of behavioural problems among children with development disorders (Emerson \& Einfeld, 2009).

Recognising deviations from typical psychosocial functioning and behaviours of a child of a certain age can enable systematic monitoring of the child and his or her overall development. This can be carried out in early and preschool educational institutions. It is clear that the participation of children in high quality programs of early and preschool education is extreme- 
određene dobi omogućuje sustavno praćenje djeteta i njegova cjelovitog razvoja, a sustav ranog i predškolskog odgoja za tu je funkciju osobito pogodan. Danas je dobro argumentirano da je sudjelovanje djece u visokokvalitetnim programima ranog i predškolskog odgoja i obrazovanja za prevenciju dugoročno nepovoljnog razvoja djece izuzetno značajno jer ima pozitivan i dugotrajan utjecaj na postignuća, napredak i psihosocijalni razvoj djece koja žive u nepovoljnim obiteljskim i socijalnim okolnostima (Taggart, Sylva, Melhuish, Sammons i Siraj, 2015). Rizik od razvoja problema u ponašanju smanjuje se ako dijete raste i razvija se u kvalitetnom okruženju jer ono pridonosi razvoju socijalnih kompetencija djeteta (Dunlap i sur., 2006), dok izostanak pravovremenog prepoznavanja problema u ponašanju dovodi do povećanja ozbiljnosti i intenziteta problema (Dunlap i sur., 2006; Beyer, Postert, Müller i Furniss, 2012; Sutherland i sur., 2018). Autori se slažu da je za prevenciju nepovoljnih razvojnih ishoda, uključujući razvoj problema u ponašanju, ključno razdoblje do šeste godine života djeteta (Reid, Littlefield i Hammond, 2008; Hartas, 2011; Glascoe, 2015; Kruizinga, 2015; Vlah i sur., 2018; Teekavanich, Chantaratin, Sirisakpanit, Tarugsa, 2017; Uğur, Yürümez i Yılmazer, 2019). Zato se univerzalno dostupne usluge u ustanovama ranog i predškolskog odgoja i obrazovanja koje su usmjerene pedagoškoj i socijalnoj podršci djeci i obiteljima smatraju važnim resursom prevencije problema u ponašanju djece (Geens i Vandenbroeck, 2013; Pölkki i Vornanen, 2015).

Međutim istraživanja ukazuju na upitne sposobnosti odgojitelja da prepoznaju probleme u ponašanju djece (Münger i Markström, 2017; Taresh, Ahmad, Roslan, Mar'of i Zaid, 2020). Izostanak pravovremenog prepoznavanja problema u ponašanju znatno umanjuje mogućnosti osiguravanja primjerenih intervencija, što se nepovoljno odražava na obrazovanje i razvoj djece (MozolicStaunton, Donelly, Yoxall i Barbaro, 2020). Cai, Kaiser i Hancock (2004) temeljem rezultata brojnih istraživanja zaključuju da se slaganja roditelja i odgojitelja u procjenama ponašanja djece kreću od slabe do srednje razine. Slaganja su veća kada se radi o lakše uočljivim problemima, a roditelji u pravilu izvještavaju o većoj prevalenciji pro- ly important for the prevention of long-term adverse developmental issues, especially because it has a positive and long-term impact on the achievements, progress, and psychosocial development of children living in unfavourable family and social circumstances (Taggart, Sylva, Melhuish, Sammons, \& Siraj, 2015). The risk of developing behavioural problems is reduced if the child grows and develops in a quality environment: such environments contribute to the development of the child's social competencies (Dunlap et al., 2006). Furthermore, the lack of timely recognition of behavioural problems can lead to an increase in their severity and intensity (Dunlap et al. et al., 2006; Beyer, Postert, Müller, \& Furniss, 2012; Sutherland et al., 2018). The period up to the child's sixth year of life is crucial for the prevention of adverse developmental outcomes, including the development of behavioural problems (Reid, Littlefield, \& Hammond, 2008; Hartas, 2011; Glascoe, 2015; Kruizinga, 2015; Vlah et al., 2018; Teekavanich, Chantaratin, Sirisakpanit, \& Tarugsa, 2017; Uğur, Yürümez, \& Y1lmazer, 2019). Therefore, universally available services in early childhood education and care institutions that are directed towards pedagogical and social support are considered to be important resources for the prevention of behavioural problems in children (Geens \& Vandenbroeck, 2013; Pölkki \& Vornanen, 2015).

However, research has suggested that the ability of preschool teachers to recognize behavioural problems in children is questionable (Münger \& Markström, 2017; Taresh, Ahmad, Roslan, Mar'of, $\&$ Zaid, 2020). The lack of timely recognition of behavioural problems significantly reduces the ability to provide appropriate interventions, which adversely affects a child's education and development (Mozolic-Staunton, Donelly, Yoxall, \& Barbaro, 2020). Cai, Kaiser and Hancock (2004) reviewed the results of several studies and concluded that the consensus between the assessment of a child's behaviour by parents and preschool teachers ranges from low to medium. This rate of agreement increases when there are more easily identifiable problems, and parents usually report a higher prevalence of problems than preschool teachers. Based on a meta-analysis of 23 studies, Carnerio et al. (2020) found that the consensus between parents and preschool teachers is weak. Research shows that preschool teachers and parents identify different behavioural problems in 
blema u usporedbi s odgojiteljima. Carneiro i sur. (2020) temeljem metaanalize 23 istraživanja također navode da su slaganja roditelja i odgojitelja slaba. Istraživanja pokazuju da odgojitelji i roditelji upućuju na različite probleme u ponašanju djece (Živčić-Bećirević i sur., 2003; Mikas, 2007; Maglica i sur., 2020). Roditelji imaju priliku promatrati dijete u obiteljskom okruženju i često ne primijete razvojno odstupanje, dok odgojitelji prate dijete u vrtićkom okruženju, unutar skupine djece iste ili slične dobi. Preporučuje se da se procjene ponašanja djece temelje na informacijama iz oba izvora (Achenbach i Ruffle, 2000; Mikas, 2007; Maglica i sur., 2020).

Značaj pravovremenog prepoznavanja i primjerenog odgovora na probleme u ponašanju djece upućuje na potrebu osiguravanja relevantnih znanstvenih uvida o pojavnosti i specifičnostima problema u ponašanju djece rane i predškolske dobi, čemu je posvećeno istraživanje prikazano u ovom radu.

\section{CILJ, PROBLEMI I HIPOTEZE ISTRAŽIVANJA}

Ovo je istraživanje usmjereno na analizu pojavnosti problema u ponašanju djece $u$ dobi od pet $i$ šest godina u Republici Hrvatskoj s obzirom na spol i razvojni status djece, temeljem procjena učestalosti manifestiranja problema u ponašanju djece od strane njihovih odgojitelja i roditelja. Njime se želi steći znanstveni uvid u mogućnosti ranog prepoznavanja problema u ponašanju djece i procijeniti relevantnost procjena ponašanja djece od strane odgojitelja i njihovih roditelja kao osoba koje s djetetom ostvaruju bliske kontakte.

Istraživanje odgovara na sljedeće istraživačke probleme:

- utvrditi učestalost manifestiranja problema u ponašanju djece rane i predškolske dobi u Republici Hrvatskoj

- usporediti procjene problema u ponašanju djece od strane roditelja i odgojitelja

- analizirati razlike u problemima u ponašanju s obzirom na spol i razvojni status djece.

Istraživanjem se provjeravaju tri hipoteze. Prvom je hipotezom pretpostavljeno da s učestalošću manifestiranja problema u ponašanju djece children (Živčić-Bećirević et al., 2003; Mikas, 2007; Maglica et al., 2020). Parents have the opportunity to observe the child in a family environment and often do not notice developmental deviations, while preschool teachers monitor the child in a kindergarten environment within a group of children of the same or similar age. Therefore, it is recommended that behavioural assessments of children must be based on information from both sources (Achenbach \& Ruffle, 2000; Mikas, 2007; Maglica et al., 2020).

The objective of this paper is to provide relevant scientific insights regarding the importance of timely recognition and appropriate response to behavioural problems in children, with a focus on the occurrence and specifics of behavioural problems in early childhood.

\section{RESEARCH GOAL, PROBLEMS, AND HYPOTHESES}

This study analysed the incidence of behavioural problems in children aged 5-6 years in the Republic of Croatia based on their sex and developmental status. The study used data based on estimates of the frequency of manifestation of behavioural problems observed in these children by their preschool teachers and parents. This research aims to provide further scientific insight into the possibility of early recognition of behaviour problems in children, and to assess the relevance of behavioural assessments made by preschool teachers and parents, since these individuals are in close contact with the child.

This study aims to address the following research problems:

- to determine the frequency of manifestations of behavioural problems in children of early and preschool age in the Republic of Croatia

- to compare the assessments of parents and preschool teachers of behavioural problems of children

- to analyse differences in behavioural problems with respect to the sex and developmental status of children.

This study tested three hypotheses. The first hypothesis assumed that with the rise increase in the frequency of manifestation of behavioural problems in children, their prevalence in the population decreases and that a smaller proportion of preschool-aged chil- 
opada njihov udio u populaciji te da izraženije probleme $u$ ponašanju manifestira manji broj djece rane i predškolske dobi (Paulus i sur., 2014; Navarro i sur., 2019). Drugom je hipotezom pretpostavljeno da su procjene problema u ponašanju djece od strane odgojitelja i roditelja međusobno komplementarne (Živčić-Bećirević i sur., 2003; Gritti i sur., 2014). Trećom je hipotezom pretpostavljeno da postoje razlike u učestalosti manifestiranja problema $u$ ponašanju djece $s$ obzirom na njihov spol (Velki i sur., 2015; Maglica i sur., 2020) i razvojni status (Hartley, Sikora i McCoy, 2008; Emerson i Einfeld, 2009; Poulou, 2015).

\section{METODE ISTRAŽIVANJA}

\section{Sudionici istraživanja}

U ovom su istraživanju korišteni podaci o 447 djece u dobi od pet i šest godina koji su uključeni u programe ranog i predškolskog odgoja i obrazovanja u 10 dječjih vrtića u Hrvatskoj.

Rani i predškolski odgoj i obrazovanje u Hrvatskoj su uređeni Zakonom o predškolskom odgoju i obrazovanju (1997) i pripadajućim podzakonskim aktima te obuhvaća odgoj, obrazovanje i skrb o djeci rane i predškolske dobi, a ostvaruje se programima odgoja, obrazovanja, zdravstvene zaštite, prehrane i socijalne skrbi za djecu od šest mjeseci do polaska u osnovnu školu. Rani i predškolski odgoj i obrazovanje čine početnu razinu odgojno-obrazovnog sustava i izuzev programa predškole (koji je obavezan za djecu u godini dana prije polaska u osnovnu školu) nije obavezan za svu djecu. Podijeljen je na dva odgojno-obrazovna ciklusa: (1) jaslički ciklus (6 mj.-3. god) i (2) vrtićki ciklus (3 god.- 7 god.).

U uzorku je 260 ili $55.7 \%$ djece u dobi od pet te 207 ili $44.3 \%$ djece u dobi od šest godina. Među njima je 225 dječaka (50.1\%) i 224 djevojčice (49.9\%). Ponašanje djece procijenile su 303 majke (86\%) i 144 oca (14\%) te 49 odgojitelja koji su u prosjeku procijenili ponašanje po devetoro djece. Oni su zaposleni u 10 dječjih vrtića koji se međusobno razlikuju po geografskom položaju, veličini i osnivaču (Tablica 1). Svi su dječji vrtići u uzorak istraživanja uključeni zbog iskazivanja interesa za sudjelovanje u istraživanju, što znači da je uzorak istraživanja prigodan. dren will manifest pronounced behavioural problems (Paulus et al., 2014; Navarro et al., 2019). The second hypothesis assumed that the assessments of children's behaviour problems made by preschool teachers and parents are mutually complementary (Živčić-Bećirević et al., 2003; Gritti et al., 2014). The third hypothesis assumed that there are significant differences in the frequency of manifestation of behavioural problems based on a child's sex (Velki et al., 2015; Nebula et al., 2020) and developmental status (Hartley, Sikora, \& McCoy, 2008; Emerson \& Einfeld, 2009; Poulou, 2015).

\section{RESEARCH METHODS}

\section{Participants}

This study analysed behavioural data collected from 447 children (aged 5-6 years) who were part of early and preschool education programs in 10 kindergartens in Croatia.

Early education and care in Croatia is regulated by the Preschool Education Act (1997) and additional secondary legislations: it includes the upbringing, education, and care of young and preschool-aged children. It is carried out through education, healthcare, nutrition, and social care programmes for children starting from the age of six months to the beginning of elementary school. Early childhood education and care is the initial level of the education system and is not compulsory, except for the preschool programme (which is compulsory for children one year prior to elementary school). It is divided into two education and care cycles: (1) the nursery cycle (six months - three years) and (2) the kindergarten cycle (3-7 years).

The sample comprises of 260 five-year-old children (55.7\%) and 207 six-year-old children (44.3\%). Among them, there were 225 boys $(50.1 \%)$ and 224 girls $(49.9 \%)$. The behaviour of the children was assessed by a total of $303(86 \%)$ mothers and $144(14 \%)$ fathers, as well as 49 preschool teachers who assessed the behaviour for an average of nine children each. These teachers are employed in the 10 kindergartens that were sampled, and these kindergartens differ from each other in geographical location, size, and organisational founder (Table 1). These kindergartens were included in the research sample since they expressed their interest in participating in the present study, making our sample a convenient, non-random sample. 
Marina Panić, Dejana Bouillet: Pojavnost problema u ponašanju djece u ustanovama ranog i predškolskog odgoja i obrazovanja / Prevalence...

Tablica 1. Struktura uzorka djece (\%) / Table 1. Sample structure (percentage of children)

\begin{tabular}{|l|c|}
\hline County & \multicolumn{1}{|c|}{ Percentage (\%) } \\
\hline City of Zagreb & 24.6 \\
\hline Zagreb County & 1.5 \\
\hline Varaždin County & 1.5 \\
\hline Međimurje County & 9.9 \\
\hline Primorje-Gorski Kotar County & 7.5 \\
\hline Osijek-Baranja County & 36.4 \\
\hline Split-Dalmatia County & \multicolumn{2}{|c|}{} \\
\hline Organisational founder & 98.5 \\
\hline City/municipality & 1.5 \\
\hline Private individual & \multicolumn{2}{|c|}{} \\
\hline Number of enrolled children & 6.4 \\
\hline Up to 150 & 35.4 \\
\hline 150 to 500 & \multicolumn{2}{|c|}{} \\
\hline 501 to 1000 & 14.1 \\
\hline 1000 to 3000 & \\
\hline Headquarters & \\
\hline City & \\
\hline Municipality & \\
\hline
\end{tabular}

\section{Mjerni instrumenti}

Podaci prikazani u ovom istraživanju izdvojeni su iz mjernih instrumenata koji su razvijeni u sklopu znanstvenog projekta Hrvatske zaklade za znanost "Modeli odgovora na odgojno-obrazovne potrebe djece izložene riziku socijalne isključenosti u ustanovama ranog i predškolskog odgoja i obrazovanja". To su Upitnik za procjenu etioloških i fenomenoloških aspekata rizika socijalne isključenosti djece rane i predškolske dobi (verzija za odgojitelje) i Upitnik za procjenu etioloških i fenomenoloških aspekata razvoja djece rane i predškolske dobi (verzija za roditelje). Obje verzije upitnika obuhvaćaju opće podatke o djetetu, karakteristikama ranog i predškolskog odgoja i obrazovanja, obiteljskim prilikama, ponašajnom, razvojnom i zdravstvenom statusu djeteta. Ovo je istraživanje temeljeno na skali od 23 čestice koje se odnose na učestalost manifestiranja 23 oblika problema u ponašanju, na petostupanjskoj skali (nikada ili rijetko, jednom mjesečno, nekoliko puta mjesečno, jednom ili više puta tjedno, svakodnevno).

\section{Prikupljanje i obrada podataka}

Podatke su prikupljale članice istraživačkog tima projekta u jesen 2020. godine pri čemu je za

\section{Instruments}

The data presented in the present study were obtained using instruments developed under the following scientific project of the Croatian Science Foundation "Models of response to educational needs of children at risk of social exclusion in ECEC institutions": Assessment of Etiological and Phenomenological Aspects of Risks of Social Exclusion of Children (version for preschool teachers) and the Questionnaire for assessing the etiological and phenomenological aspects of development of children of early and preschool age (version for parents). Both questionnaires included items related to general data on the child, characteristics of early and preschool education, family circumstances, as well as the behavioural, developmental, and health status of the child. This study is based on a scale of 23 items related to the frequency of manifestations of 23 forms of behavioural problems that were measured on a five-degree scale ("never or rarely", "once a month", "several times a month", "once or more a week", and "daily").

\section{Data collection and analysis}

Data were collected in fall 2020 by members of the research team and one scientist was in charge of each kindergarten involved. A written invitation was sent to the directors of the early childhood education 
svaki uključeni dječji vrtić bila zadužena jedna znanstvenica. Ravnateljima dječjih vrtića upućen je pisani poziv za sudjelovanje $u$ istraživanju $u$ kojem je objašnjena svrha i metoda istraživanja, na temelju pisane suglasnosti za provedbu istraživanja od strane ministarstva nadležnog za obrazovanje. Prije prikupljanja podataka održana je edukacija odgojitelja u svakom dječjem vrtiću. Istraživanje ima suglasnost Etičkog odbora Učiteljskog fakulteta Sveučilišta u Zagrebu jer poštuje etičke standarde Etičkog kodeksa Sveučilišta u Zagrebu, kao i druge relevantne dokumente.

Istraživačice su za svako dijete uključeno u istraživanje osigurale pisani informirani pristanak njihovih roditelja i odgojitelja i osigurale zaštitu osobnih podataka djece, roditelja i odgojitelja. Podaci su obrađeni primjenom faktorske analize i neparametrijskim Spearmanovim koeficijentom korelacija, Wilcoxonovim i Mann-Whitneyevim testom.

\section{REZULTATI I RASPRAVA}

Podaci o ponašanju djece prikupljeni od roditelja i odgojitelja grupirani su metodom glavnih komponenti (uz kosokutnu rotaciju). Prikladnost procjena ponašanja djece za korištenje metode glavnih komponenti provjerena je Kaiser-Meyer Olkinovom koeficijentom, koji iznosi 0.919 (procjene odgojitelja) i 0.894 (procjene roditelja) te Bartlettovim testom sfericiteta $\left(\chi^{2}=8081,669 ; \mathrm{df}\right.$ $=276 ; \mathrm{p}=0.000$ za procjene odgojitelja te $\chi^{2}=$ 4298,$402 ; \mathrm{df}=276 ; \mathrm{p}=0.000$ za procjene roditelja). Sukladno teorijski pretpostavljenom modelu o dvije grupe problema u ponašanju (eksternalizirana i internalizirana ponašanja) 23 čestice grupirane su u dvije komponente. One ukupno objašnjavaju $56.05 \%$ zajedničke varijance (u slučaju procjena odgojitelja) i 41.13\% zajedničke varijance (u slučaju procjena roditelja). Cronbach Alpha koeficijent za procjene odgojitelja iznosi 0.911 , a za procjene roditelja 0.895 .

Podaci prikazani u Tablici 2 upućuju na zaključak da su procjene ponašanja djece od strane odgojitelja i roditelja međusobno podudarne jer su ista ponašanja grupirana u komponentu koja se odnosi na eksternalizirana ponašanja (prva komponenta) i internalizirana ponašanja (druga komponenta), and care institutions describing the main purpose and methodology of the study in order to obtain written consent based on the guidelines for the research outlined by the Ministry of Education. Before collecting the data, an education for preschool teachers was held in each early childhood and care institution. The study was approved by the Ethics Committee of the Faculty of Teacher Education, University of Zagreb, and complies with ethical standards outlined in the Ethical Code of the University of Zagreb, as well as with other applicable regulations.

Written informed consent was provided by the parents and the preschool teachers for each child to be included in the research study. All participants (children, parents and preschool teachers) were informed that their personal data would be protected. All data were analysed using factor analysis, nonparametric Spearman rank correlation, Wilcoxon signed rank test, and Mann-Whitney U test.

\section{RESULTS AND DISCUSSION}

Data regarding the children's behaviour collected from parents and preschool teachers were grouped based on the principal components method (oblimin rotation). The suitability of using the principal components method for children's behavioural assessments was verified using the Bartlett sphericity test $\left(\chi^{2}=\right.$ 8081,$669 ; \mathrm{df}=276 ; \mathrm{p}=0.000$ for preschool teacher assessments and $\chi^{2}=4298,402 ; \mathrm{df}=276 ; \mathrm{p}=0.000$ for the parent assessments), as well as the Kaiser-Meyer Olkin coefficient, which was calculated as 0.919 for the preschool teacher assessments and 0.894 for the parent assessments. Based on the theoretically assumed model where there are two groups of behavioural problems (externalised and internalised behaviours), the 23 questionnaire items were grouped into two components. These items explained a total of $56.05 \%$ of the common variance in the case of the preschool teacher assessments and $41.13 \%$ of the common variance in the case of the parent assessments. Cronbach's Alpha for the preschool teacher assessments was 0.911 and for the parent assessments was 0.895 .

The data shown in Table 2 suggests that assessments of children's behaviour by preschool teachers and parents are mutually consistent because the same behaviours were grouped into the component related to externalised behaviours (first component) and that 
Marina Panić, Dejana Bouillet: Pojavnost problema u ponašanju djece u ustanovama ranog i predškolskog odgoja i obrazovanja / Prevalence...

Tablica 2. Struktura, postotak objašnjene varijance i Cronbach Alpha koeficijent ekstrahiranih komponenti / Table 2. Structure, percentage of explained variance and the Cronbach Alpha coefficient of the extracted components.

\begin{tabular}{|c|c|c|c|c|}
\hline Item & Preschool & assessment & Pare & ment \\
\hline How often does the child ... & 1 & 2 & 1 & 2 \\
\hline resist following instructions & 0.877 & & 0.807 & \\
\hline express anger inappropriately & 0.870 & & 0.726 & \\
\hline break pre-arranged rules of conduct & 0.861 & & 0.673 & \\
\hline ignore instructions from adults & 0.845 & & 0.800 & \\
\hline defy adults & 0.821 & & 0.812 & \\
\hline show impulsiveness & 0.779 & & 0.678 & \\
\hline engage in verbal conflicts with other children & 0.776 & & 0.532 & \\
\hline engage in physical conflicts with other children & 0.768 & & 0.408 & \\
\hline disrupt group activities & 0.775 & & 0.512 & \\
\hline show difficulties in paying attention & 0.747 & & 0.59 & \\
\hline manifest irritability & 0.729 & & 0.643 & \\
\hline impose their own opinions or desires & 0.695 & & 0.669 & \\
\hline engage in verbal conflicts with adults & 0.642 & & 0.750 & \\
\hline show discomfort when approaching other children or adults & & 0.782 & & 0.644 \\
\hline show fear related to speaking in front of children or adults & & 0.757 & & 0.677 \\
\hline show fear related to participating in activities or events & & 0.752 & & 0.675 \\
\hline seem withdrawn & & 0.748 & & 0.683 \\
\hline manifest solitude & & 0.707 & & 0.507 \\
\hline worry about making a mistake & & 0.702 & & 0.648 \\
\hline manifest confusion & & 0.669 & & 0.535 \\
\hline manifest sorrow without an observable cause & & 0.557 & & 0.475 \\
\hline cry & & 0.539 & & 0.484 \\
\hline manifest a high degree of self-criticism & & 0.352 & & 0.619 \\
\hline PERCENTAGE OF VARIANCE EXPLAINED & 36.99 & 19.06 & 29.42 & 11.72 \\
\hline CRONBACH'S ALPHA & 0.927 & 0.859 & 0.899 & 0.795 \\
\hline
\end{tabular}

neovisno o tome procjenjuju li ponašanja djece odgojitelji ili roditelji. Međutim izostala je statistički značajna povezanost procjena eksternaliziranih problema u ponašanju djece od strane odgojitelja i procjena internaliziranih problema $u$ ponašanju djece od strane roditelja iako su eksternalizirani problemi pozitivno i statistički značajno povezani s internaliziranim problemima i prema procjenama roditelja i prema procjenama odgojitelja. Ta je povezanost izraženija kada ponašanje djece procjenjuju roditelji, u odnosu na procjene odgojitelja (Tablica 3). Ovi su rezultati u skladu s ranijim istraživanjima koja potvrđuju da roditelji i odgojitelji probleme vide i tumače na različite načine iako se suštinski slažu (Mikas, 2007; Maglica i sur., 2020).

Analiza procjena učestalosti manifestiranja problema u ponašanju djece rane i predškolske dobi pokazala je da ih prema procjenama related to internalised behaviours (second component) regardless of whether they were assessed by preschool teachers or parents. However, there was no statistically significant correlation between the assessments of externalised problems in children's behaviour by preschool teachers and the assessments of internalised problems in children's behaviour by parents. The externalized problems were positively and statistically significantly related to internalised problems according to both parents and preschool teachers. This correlation is more pronounced when children's behaviour is assessed by parents rather than by preschool teachers (Table 3 ). These results are consistent with previous research that confirms that parents and preschool teachers see and interpret problems in different ways, although they essentially agree (Mikas, 2007; Maglica et al., 2020).

The estimation of the frequency of manifestations of behavioural problems in preschool-aged children 
Tablica 3. Spearmanov koeficijent korelacija među glavnim komponentama / Table 3. Spearman rank correlation coefficients between the main components

\begin{tabular}{|l|c|c|c|c|}
\hline \multirow{2}{*}{ Component } & \multicolumn{2}{|c|}{ Preschool teacher assessments } & \multicolumn{2}{c|}{ Parent assessments } \\
\cline { 2 - 5 } & Externalized BP & Internalized BP & Externalized BP & Internalized BP \\
\hline Externalized BP - preschool teachers & 1 & $0.187^{* *}$ & $0.286^{* *}$ & -0.037 \\
\hline Internalized BP - preschool teachers & & 1 & 0.045 & $0.228^{* *}$ \\
\hline Externalized BP - parents & & & 1 & $0.459^{* *}$ \\
\hline Internalized BP - parents & & & & 1 \\
\hline
\end{tabular}

$* *$ indicates $\mathrm{p}<0.001$

Tablica 4. Učestalost manifestiranja problema u ponašanju djece (\%) / Table 4. Frequency of manifested behavioural problems in children (\%)

\begin{tabular}{|l|c|c|c|c|}
\hline \multirow{2}{*}{ Frequency of behaviour } & \multicolumn{2}{|c|}{ Preschool teacher assessments } & \multicolumn{2}{c|}{ Parent assessments } \\
\cline { 2 - 5 } & Externalized BP & Internalized BP & Externalized BP & Internalized \\
\hline Never or rarely & 60 & 56.7 & 22.8 & 45.2 \\
\hline Once a month & 25.6 & 35.3 & 53.4 & 47.8 \\
\hline Several times a month & 7.4 & 4.9 & 14.4 & 6.0 \\
\hline One or more times a week & 5.5 & 2.7 & 8.4 & 1 \\
\hline Daily & 1.5 & 0.4 & 1 & 0 \\
\hline
\end{tabular}

odgojitelja jednom tjedno ili češće manifestira $7 \%$ djece, a prema procjenama roditelja $9.4 \%$ (Tablica 4). Istovremeno odgojitelji internalizirane probleme u ponašanju djece primjećuju češće no što je to slučaj s njihovim roditeljima $(3.1 \%$ u odnosu na $1 \%$ ). U uzorku je znatna pojavnost djece koja probleme u ponašanju manifestiraju nekoliko puta mjesečno, što je u skladu s razvojnom dobi djeteta i očekuje se da će većina te djece, uz razvojno i pedagoški primjerene poticaje, usvojiti društveno prihvatljiva i individualno djelotvorna ponašanja.

Wilcoxonov test ukazuje na statistički značajne razlike u procjenama eksternaliziranih i internaliziranih problema u ponašanju djece $s$ obzirom na to procjenjuju li ponašanja odgojitelji ili roditelji (za eksternalizirana ponašanja iznosi $\mathrm{W}=$ $-10.600, \mathrm{p}=0.000$, a za internalizirana $\mathrm{W}=-2.631$, $\mathrm{p}=0.009)$.

Rezultati o procjenama učestalosti problema $\mathrm{u}$ ponašanju djece rane i predškolske dobi jesu unutar raspona udjela djece rane i predškolske dobi s problemima u ponašanju dobivenih ranijim istraživanjima (Vlah i sur., 2018; Navarro i sur., 2019). Zbog potrebe razlikovanja ozbiljnijih problema od razvojno uvjetovanih i prolaznih odstupanja $u$ ponašanju, $u$ grupu djece s problemima $u$ ponašanju svrstana su samo ona koja zbog svoje showed that, according to preschool teachers, $7 \%$ of children manifested such problems once a week or more often, and according to the parents, $9.4 \%$ of children manifested such problems once a week or more often (Table 4). At the same time, preschool teachers noticed internalised behavioural problems in children more often than their parents (3.1 vs $1 \%$ ). The sample shows a significant incidence of children who manifest behavioural problems several times a month, which is consistent with the child's developmental age. It is expected that most of these children can adopt socially acceptable and individually effective behaviours when they are provided with developmentally and pedagogically appropriate incentives.

The Wilcoxon test indicates statistically significant differences in the assessments of externalised and internalised behavioural problems in children, depending on whether the behaviours are assessed by preschool teachers or parents (for externalized behaviours: $\mathrm{W}=-10.600, \mathrm{p}=0.000$; for internalized behaviours: $\mathrm{W}=-2.631, \mathrm{p}=0.009$ ).

The results on estimates of the frequency of behavioural problems observed in early and preschool-aged children are within the range of the proportions of early and preschool children with behavioural problems reported in previous studies (Vlah et al., 2018; Navarro et al., 2019). Given the need to distinguish more serious problems 
Marina Panić, Dejana Bouillet: Pojavnost problema u ponašanju djece u ustanovama ranog i predškolskog odgoja i obrazovanja / Prevalence...

Tablica 5. Učestalost manifestiranja problema u ponašanju djece s obzirom na spol djeteta / Table 5. Frequency of manifested behavioural problems in children based on the sex of the child

\begin{tabular}{|l|c|c|c|c|}
\hline Component BP & Girls - rank & Boys - rank & Mann-Whitney U & Z \\
\hline Externalised BP - preschool teachers & 199.85 & 240.06 & 19676.500 & $-3.343^{* *}$ \\
\hline Internalised BP - preschool teachers & 216.11 & 218.92 & 23238.000 & -0.234 \\
\hline Externalised BP - parents & 191.32 & 218.61 & 18119.500 & $-2.336^{* *}$ \\
\hline Internalised BP - parents & 205.42 & 192.54 & 18422.500 & 1.121 \\
\hline
\end{tabular}

$* *$ indicates $p \leq 0.01$

Tablica 6. Učestalost manifestiranja problema u ponašanju djece s obzirom na uključenost djeteta u rad s logopedom ili s edukacijskim rehabilitatorom / Table 6. Frequency of manifested behavioural problems in children based on whether they were included or not in treatment programs provided by speech therapists and/or educational rehabilitators

\begin{tabular}{|l|c|c|c|c|}
\hline BP Components & $\begin{array}{c}\text { Child not in } \\
\text { treatment }\end{array}$ & Child in treatment & Mann-Whitney U & Z \\
\hline Externalized BP - preschool teachers & 223.77 & 242.88 & 19014.500 & -1.388 \\
\hline Internalized BP - preschool teachers & 219.05 & 246.89 & 17558.000 & $-2.013^{*}$ \\
\hline Externalized BP - parents & 203.19 & 221.92 & 15999.000 & -1.433 \\
\hline Internalized BP - parents & 192.54 & 226.27 & 13643.000 & -2.616 \\
\hline
\end{tabular}

$* * p \leq 0.05$

učestalosti ukazuju na mogućnost razvoja dugoročnijih teškoća jer su kontinuitet $\mathrm{i}$ intenzitet među važnijim kriterijima za utvrđivanje problema u ponašanju (Koller-Trbović i sur., 2011). Vidljivo je da roditelji zamjećuju veću učestalost problema u ponašanju djece u odnosu na odgojitelje, što je u skladu s ranijim istraživanjima koja upućuju na takav trend (Cai, Kaiser i Hancock, 2004; Carneiro i sur., 2020).

Prema rezultatima Mann-Whitneyeva testa (Tablica 5) utvrđene su razlike s obzirom na spol u procjeni manifestiranja eksternaliziranih ponašanja, neovisno o tome procjenjuju li ponašanja odgojitelji ili roditelji djece, dok internalizirana ponašanja ujednačeno manifestiraju djevojčice $i$ dječaci. Eksternaliziranim problemima u ponašanju skloniji su dječaci. Dok su rodne razlike u eksternaliziranim problemima u ponašanju dobro poznate i dokumentirane, na ujednačenost zastupljenosti internaliziranih problema u ponašanju među dječacima i djevojčicama upućuju rijetka istraživanja (Rescorla i sur., 2012; Paulus i sur., 2014).

Kao pokazatelj razvojnog statusa djece u ovom su istraživanju korištene informacije o uključenosti djece $u$ rad s logopedom i/ili edukacijskim rehabilitatorom prema informacijama dobivenima od from developmentally conditioned and transient behavioural disorders, the group of children with behavioural problems includes only those who, due to their frequency, indicate the possibility of developing long-term difficulties: this is critical since continuity and intensity are among the most important criteria for identifying behavioural problems (Trbović et al., 2011). Consistent with previous studies (Cai, Kaiser \& Hancock, 2004; Carnerio et. al, 2020) it is obvious that parents estimate a higher frequency of manifested problems in children then preschool teachers.

According to the results of the Mann-Whitney $\mathrm{U}$ test (Table 5), gender differences were found in the assessment of the manifestation of externalised behaviours, regardless of whether the behaviours were assessed by preschool teachers or parents of children, while internalised behaviours were equally manifested by girls and boys. Boys are more prone to externalised behavioural problems. While gender differences in externalised behavioural problems are well documented, the uniformity of the prevalence of internalised behavioural problems among boys and girls has been rarely reported (Rescorla et al., 2012; Paulus et al., 2014).

As an indicator of the developmental status of children, the present study analysed information obtained from the parents on the involvement of children in 
roditelja djece. Takav je pristup odabran jer je na istom uzorku ispitanika utvrđeno da je uključenost djece $u$ ove tretmane pouzdan prediktor njihovih teškoća u razvoju (Bouillet i Antulić Majcen, u tisku). U rad s logopedom uključeno je čak $25.5 \%$ $(\mathrm{N}=119)$ djece, a tek $1.3 \%(\mathrm{~N}=6) \mathrm{u}$ rad s edukacijskim rehabilitatorom. Troje djece $(0.6 \%)$ istovremeno je uključeno i u rad s logopedom i u rad s edukacijskim rehabilitatorom. Ukupno je u neki tretman uključeno 128 ili $27.4 \%$ djece, a 339 ili $72.6 \%$ nije. Razlike u manifestiranju problema $\mathrm{u}$ ponašanju prema tom kriteriju prikazane su u Tablici 6.

Rezultati Mann-Whitneyeva testa učestalosti manifestiranja problema u ponašanju s obzirom na okolnost je li dijete uključeno ili nije uključeno $\mathrm{u}$ rad s logopedom i/ili edukacijskim rehabilitatorom pokazuju da djeca koja su uključena u navedeno statistički značajno češće manifestiraju internalizirane probleme u ponašanju, neovisno o tome radi li se o procjenama odgojitelja ili roditelja. S druge strane razlike u eksternaliziranim problemima u ponašanju djece nisu utvrđene. $U$ literaturi prevladava stajalište da djeca s teškoćama u razvoju češće od standardno razvijenih vršnjaka manifestiraju eksternalizirane i internalizirane probleme (npr. Hartley i sur., 2008; Emerson i Einfeld, 2009; Poulou, 2015), a ovo istraživanje taj podatak relativizira. Prema tome prilikom razmatranja povezanosti teškoća u razvoju i problema u ponašanju, u obzir je važno uzeti i druge karakteristike djeteta (uvjeti u kojima živi, vrsta teškoće u razvoju, dostupna podrška i dr.), a pozornost je važno usmjeriti na ponašanja koja za okolinu nisu ometajuća, a mogu ugroziti mentalno zdravlje djece.

\section{ZAKLJUČAK}

Sve su postavljene hipoteze potvrđene jer se pokazalo da s povećanom učestalošću manifestiranja problema u ponašanju djece opada njihov udio u populaciji te da izraženije probleme u ponašanju prema procjenama odgojitelja i roditelja manifestira manji broj djece rane i predškolske dobi. Također je potvrđeno da su procjene problema u ponašanju djece od strane odgojitelja i roditelja međusobno komplementarne, ali ne i jednoznačne. the treatment of speech therapists and/or educational rehabilitators. This approach was chosen because it has already been established that the involvement of children in such treatment is a reliable predictor of their developmental difficulties based on the same sample of participants (Bouillet \& Antulić Majcen, in press). As many as $25.5 \%(n=119)$ of children were included in the treatment program provided by speech therapists, while only $1.3 \%(n=6)$ were included in the treatment program provided by an educational rehabilitator. Three children $(0.6 \%)$ were included in both treatment programs offered by speech therapists and educational rehabilitators. In the present study, we analysed the differences in the manifestation of behavioural problems among a total of 128 children $(27.4 \%)$ who were included in at least one treatment, as well as among the 339 children (72.6\%) who were not included in any treatment (Table 6).

The results of the Mann-Whitney U test showed that children involved in treatment programs offered by speech therapists/educational rehabilitators were more likely to manifest internalised behavioural problems, regardless of whether the data was based on the assessments of preschool teachers or parents. On the other hand, differences in externalised behavioural problems in children have not been identified. The prevailing view in the literature is that children with developmental disabilities are more likely to manifest externalised and internalised problems than their typically developed peers (e.g., Hartley et al., 2008 Emerson \& Einfeld, 2009; Poulou, 2015), and the present study considers this data. Therefore, when considering the relationship between developmental difficulties and behavioural problems, it is important to take into account other characteristics of the child (living conditions, type of developmental difficulties, and available support), as well as to focus on behaviours that are not disruptive to the environment, but can endanger the mental health of children.

\section{CONCLUSION}

These findings confirm all three research hypotheses: the data has confirmed that an increase in the frequency of manifestations of children's behavioural problems is followed by a decrease in their share in the population; also, pronounced behavioural problems (according to preschool teachers and parents) were manifested by a smaller 
Rezultati istraživanja koji su prikazani u ovom radu nisu provedeni na uzorku reprezentativnom za Republiku Hrvatsku i procjene problema u ponašanju djece nisu dodatno provjeravane dijagnostičkim instrumentima. Ipak, istraživanje potvrđuje mogućnosti ranog prepoznavanja problema u ponašanju djece i ukazuje na relevantnost procjena ponašanja djece od strane odgojitelja i njihovih roditelja. Procijenjeno je da dječaci u odnosu na djevojčice češće manifestiraju eksternalizirane probleme u ponašanju, dok u uzorku nisu pronađene razlike u manifestiranju internaliziranih problema u ponašanju. Odgojitelji i roditelji kod djece koja su uključena u rad s logopedom ili edukacijskim rehabilitatorom u usporedbi s tipično razvijenom djecom češće primjećuju internalizirane probleme u ponašanju iako ovi nalazi mogu biti posljedica drugačijeg tumačenja i percepcije ponašanja djece $\mathrm{s}$ teškoćama u razvoju u usporedbi s ponašanjem tipično razvijene djece, ali i drugačijeg tumačenja ponašanja djevojčica i dječaka.

Ovdje je važno naglasiti da su odgojitelji i roditelji ponašanje djece procjenjivali istim mjernim instrumentom, ali u različitim kontekstima. Tako su se roditelji usmjeravali na ponašanja djece $u$ obiteljskom, a odgojitelji na ponašanja djece $u$ institucijskom kontekstu.

Ovim je istraživanjem ustanovljeno da prema procjenama odgojitelja eksternalizirane probleme $u$ ponašanju učestalo manifestira $7 \%$, a prema procjenama roditelja $9 \%$ djece. Učestalo manifestiranje internaliziranih problema u ponašanju odgojitelji su procijenili kod 3\%, a roditelji kod svega $1 \%$ djece. Razlike u procjenama mogu biti posljedica drugačijih obrazaca ponašanja djece $u$ institucijskom i obiteljskom okruženju, kao i okolnosti da odgojitelji u odnosu na roditelje imaju više mogućnosti usporedbe ponašanja nekog djeteta u odnosu na njegove vršnjake. Usto vjerojatno neka ponašanja djece roditelji i odgojitelji tumače na različite načine pridajući im različita značenja. Tako roditelji ne moraju nužno biti svjesni razvojne uvjetovanosti nekih oblika ponašanja djece, dok se od odgojitelja očekuje dobro poznavanje razvojnih faza i njihova utjecaja na ponašanje djeteta.

Pokazalo se da je u procesima rane identifikacije problema u ponašanju djece važno uspostaviti kvalitetnu suradnju između roditelja i odgojitelja proportion of preschool-aged children; finally, data confirmed that the behavioural assessments made by preschool teachers and parents are complementary, but not unequivocal.

The results of the present study were obtained from a sample that was not representative of the Republic of Croatia and the assessments of children's behavioural problems were not thoroughly checked using standardized diagnostic instruments. Nevertheless, these findings confirm the possibility of the early recognition of problems in children's behaviour and indicates the relevance of behavioural assessments made by preschool teachers and parents.

It was estimated that boys were more likely to manifest externalised behavioural problems than girls, while no differences were observed between the two groups in the manifestation of internalised behavioural problems. Compared to typically developed children, preschool teachers and parents were more likely to notice internalised behavioural problems in children involved in the treatment program offered by speech therapists or educational rehabilitators. Although these findings can be interpreted in different ways based on the perception of the behaviour of children with disabilities and that of typically developed children, as well as the differential behaviours exhibited by boys and girls.

It is important to emphasise that teachers and parents assessed the behaviour of the children using the same instrument, but in different contexts. Thus, parents focused on the behaviour of children in a family context, and teachers on the children's behaviour in an institutional context.

In this study, it was found that preschool teachers estimated a 7\% frequency of externalised behavioural problems in children while parents estimated a frequency of $9 \%$. Similarly, the manifestation of internalised behavioural problems occurs in $3 \%$ of children according to preschool teachers, and in $1 \%$ according to parents. Differences in assessments may be due to different patterns of behaviour in the institutional and family environment, as well as the fact that preschool teachers have more opportunities to observe a child's behaviour in comparison with her/his peers. Additionally, certain behaviours can be interpreted 
kako bi se osigurala pravovremena intervencija kojom će se prevenirati razvoj problema u ponašanju male djece. Tom se suradnjom omogućuje preventivno djelovanje ustanova ranog i predškolskog odgoja i obrazovanja kako u radu s djecom tako i $\mathrm{u}$ radu s roditeljima, tako da djeca u oba okruženja (obiteljskom i institucijskom) budu usmjeravana prema društveno prihvatljivim i individualno djelotvornim ponašanjima. Rezultati ovog istraživanja potvrđuju ranije dobivene nalaze o prevalenciji problema u ponašanju djece rane i predškolske dobi i mogućnostima planiranja preventivnih programa temeljem procjena odgojitelja i roditelja djece. in different ways by parents and educators, giving them different meanings. Thus, parents don't necessarily have to be aware of the developmental conditionality of certain types of children's behaviour, while educators are expected to have a better knowledge of the developmental stages and their impact on the child's behaviour.

These results show that, in the process of early identification of children's behavioural problems, it is important to establish a cooperative relationship between their parents and preschool teachers in order to ensure timely intervention for the prevention of development of behavioural problems in young children. Such cooperation allows for the development of preventative action initiatives in early and preschool educational institutions: these initiatives must target working with children and working with parents, so that children can be directed towards socially acceptable and individually effective behaviours in both environments (family and institutional). The results of the present study confirmed previous findings about the prevalence of behavioural problems in early childhood and highlight the importance of planning prevention programs based on the assessments made by parents and teachers. 
Marina Panić, Dejana Bouillet: Pojavnost problema u ponašanju djece u ustanovama ranog i predškolskog odgoja i obrazovanja / Prevalence...

\section{REFERENCES}

Achenbach, T. M. \& Ruffle, T. M. (2000). The Child Behavior Checklist and Related Forms for Assessing Behavioral/ Emotional Problems and Competencies. Pediatrics in Review, 21(8), 265-271.

Beyer, T., Postert, C., Müller, J. M. \& Furniss, T. (2012). Prognosis and Continuity of Child Mental Health Problems from Preschool to Primary School: Results of a Four-Year Longitudinal Study. Child Psychiatry \& Human Development, 43(4), 533-543. doi: 10.1007/s10578-012-0282-5

Bhopal S, Roy R, Verma D, Kumar D, Avan B, Khan B, Gram, L., Sharma, K., Amenga-Etego, S., Pancal, S. N., Soremekun, S., Divan, G., \& Kirwood, B. R. (2019). Impact of adversity on early childhood growth \& development in rural India: Findings from the early life stress sub-study of the SPRING cluster randomised controlled trial (SPRING-ELS). PLoS ONE, 14(1): e0209122, 1-19. https://doi.org/10.1371/journal.pone.0209122

Bijedić, M., Kuralić Čišić, L., Jahić, A. \& Muminović Vildić, M. (2019). Samoprocjena promjena ponašanja učenika osnovnih škola s problemima u ponašanju nakon sudjelovanja u socijalnopedagoškim intervencijama. Kriminologija \& socijalna integracija, 27(1), 68-83. doi: https://doi.org/10.31299/ksi.27.1.3

Bouillet, D. (2019). Inkluzivno obrazovanje: odabrane teme. Zagreb: Sveučilište u Zagrebu, Učiteljski fakultet.

Bouillet, D. \& Antulić Majcen, S. (2021). Risks of social exclusion among young and preschool children: assessments by parents and ECEC professionals. Journal of Early Childhood Research, u tisku

Brown, C. L., Gibbons, L. E., Kennison, R. F., Robitaille, A., Lindwall, M., Mitchell, M. B., Shirk, S. D., Atri, A., Cimino, C. R., Benitez, A., MacDonald S. W. S., Zelinski, E. M., Willis, S. L., Schaie, W., Johansson, B., Dixon, R. A., Mungas, D. M., Hofer, S. M. \& Piccinin, A. M. (2012). Social Activity and Cognitive Functioning Over Time: A Coordinated Analysis of Four Longitudinal Studies. Journal of Aging Research, 2012, 1-12. doi: $10.1155 / 2012 / 287438$

Cai, X., Kaiser, A. P., \& Hancock, T. B. (2004). Parent and Teacher Agreement on Child Behavior Checklist Items in a Sample of Preschoolers From Low-Income and Predominantly African American Families. Journal of Clinical Child \& Adolescent Psychology, 33(2), 303-312. doi:10.1207/s15374424jccp3302_12

Carneiro, A., Soares, I., Rescorla, L., \& Dias, P. (2020). Meta-Analysis on Parent-Teacher Agreement on Preschoolers' Emotional and Behavioural Problems. Child Psychiatry \& Human Development, 52(4), 609-618. doi:10.1007/ s10578-020-01044-y

Cicchetti, D. i Toth, S. L. (2014). Internalizing and Externalizing Expressions of Dysfunction. New York: Psychology Press. doi: https://doi.org/10.4324/9781315807256

Das, M., Elsey, H., Shawon, R.A., Hicks, R. A., Ferdoush, J., Huque, R., Fieroze, F., Nasreen, Sh., Wallance, H., \& Mashreky, S. (2018). Protocol to develop sustainable day care for children aged 1-4 years in disadvantaged urban communities in Dhaka, Bangladesh. BMJ Open, 8: e024101, 1-10. doi:10.1136/ bmjopen-2018-024101

Dunlap, G., Strain, P. S., Fox, L., Carta, J. J., Conroy, M., Smith, B. J., Kern, L., Hemmeter, M. L., Timm, M. A., McCart, A., Sailor, W., Markey, U., Markey, D. J., Sharon, L. \& Sowell, C. (2006). Prevention and Intervention with Young Children's Challenging Behavior: Perspectives regarding Current Knowledge. Behavioral Disorders, 32(1), 29-45.

Emerson, E., i Einfeld, S. L. (2011). Challenging behaviour. New York: Cambridge University Press.

Emerson, E., \& Einfeld, S. (2009). Emotional and behavioural difficulties in young children with and without developmental delay: a bi-national perspective. Journal of Child Psychology and Psychiatry, 51(5), 583593. doi:10.1111/j.1469-7610.2009.02179.x

Furniss, T., Beyer, T., \& Guggenmos, J. (2006). Prevalence of behavioural and emotional problems among sixyears-old preschool children. Social Psychiatry and Psychiatric Epidemiology, 41(5), 394-399. doi: 10.1007/ s00127-006-0045-3

Geddes, R., Frank, J., \& Haw, S. (2011). A rapid review of key strategies to improve the cognitive and social development of children in Scotland. Health Policy, 101(1), 20-28. doi: 10.1016/j.healthpol.2010.08.013 
Geens, N., \& Vandenbroeck, M. (2013). Early childhood education and care as a space for social support in urban contexts of diversity. European Early Childhood Education Research Journal, 21(3), 407-419. doi:10.1080/13 50293x.2013.814361

Glascoe, F. P. (2015). Evidence-Based Early Detection of Developmental-Behavioral Problems in Primary Care: What to Expect and How to Do It. Journal of Pediatric Health Care, 29(1), 46-53. doi: 10.1016/j.pedhc.2014.06.005

Gritti, A., Bravaccio, C., Signoriello, S., Salerno, F., Pisano, S., Catone, G., Gallo, C. \& Pascotto, A. (2014). Epidemiological study on behavioural and emotional problems in developmental age: prevalence in a sample of Italian children, based on parent and teacher reports. Italian Journal of Pediatrics, 40(1), 19, 1-7. doi: $10.1186 / 1824-7288-40-19$

Hartas, D. (2011). Children's language and behavioural, social and emotional difficulties and prosocial behaviour during the toddler years and at school entry. British Journal of Special Education, 38(2), 83-91. doi: 10.1111/j.14678578.2011.00507.x

Hartley, S. L., Sikora, D. M., \& McCoy, R. (2008). Prevalence and risk factors of maladaptive behaviour in young children with Autistic Disorder. Journal of Intellectual Disability Research, 52(10), 819-829. doi: 10.1111/j.13652788.2008.01065.x

Klarin, M. \& Đerđa, V. (2014). Roditeljsko ponašanje i problemi u ponašanju kod adolescenata. Ljetopis socijalnog rada, 21(2), 243-262. doi: https://doi.org/10.3935/ljsr.v21i2.17

Koller-Trbović, N., Žižak, A. \& Jeđud Borić, I. (2011). Standardi za terminologiju, definiciju, kriterije i način praćenja pojave poremećaja u ponašanju djece i mladih. Povjerenstvo za prevenciju poremećaja u ponašanju djece i mladih Vlade Republike Hrvatske. Zagreb: Ministarstvo obitelji, branitelja i međugeneracijske solidarnosti.

Kruizinga, I. (2015). Early detection of emotional and behavioural problems in preschool children. Rotterdam: Nederlands.

Macuka, I. (2016). Emocionalni i ponašajni problemi mlađih adolescenata - zastupljenost i rodne razlike. Ljetopis socijalnog rada, 23(1), 65-86. doi: https://doi.org/10.3935/ljsr.v23i1.97

Macuka, I., Smojver-Ažić, S. \& Burić, I. (2012). Posredujuća uloga emocionalne regulacije u odnosu roditeljskog ponašanja i prilagodbe mlađih adolescenata. Društvena istraživanja, 21(2(116)), 383-403. doi: https://doi. org/10.5559/di.21.2.05

Maglica, T. \& Džanko, P. (2016). Internalizirani problemi u ponašanju među splitskim srednjoškolcima. Školski vjesnik, 65(4), 559-585.

Maglica, T., Reić Ercegovac, I. \& Ljubetić, M. (2020). Mindful parenting and behavioural problems in preschool children. Hrvatska revija za rehabilitacijska istraživanja, 56(1), 44-57. doi: https://doi.org/10.31299/hrri.56.1.4

McCoy, D. C., Peet, E. D., Ezzati, M., Danaei, G., Black, M. M., Sudfeld, C. R., Fawzi, W. \& Fink, G. (2016). Early Childhood Developmental Status in Low- and Middle-Income Countries: National, Regional, and Global Prevalence Estimates Using Predictive Modeling. PLOS Medicine, 13(6), 1-18. doi: 10.1371/journal.pmed.1002034

Mikas, D. (2007). Kako roditelji i odgojitelji procjenjuju emocionalni razvitak i ponašanje djece predškolske dobi. Odgojne znanosti, 9(1(13)), 49-74.

Mozolic-Staunton, B., Donelly, M., Yoxall, J., \& Barbaro, J. (2020). Early detection for better outcomes: Universal developmental surveillance for autism across health and early childhood education settings. Research in Autism Spectrum Disorders, 71, 101496, 1-14. doi: 10.1016/j.rasd.2019.101496

Münger, A.-C. \& Markström, A.-M. (2017). Recognition and identification of children in preschool and school who are exposed to domestic violence. Education Inquiry, 9(3), 299-315. doi: 10.1080/20004508.2017.1394133

Navarro, J.-B., Fernández, M., de la Osa, N., Penelo, E., \& Ezpeleta, L. (2019). Warning signs of preschool victimization using the strengths and difficulties questionnaire: Prevalence and individual and family risk factors. PLOS ONE, 14(8): e0221580, 1-19. doi: 10.1371/journal.pone.0221580 
Marina Panić, Dejana Bouillet: Pojavnost problema u ponašanju djece u ustanovama ranog i predškolskog odgoja i obrazovanja / Prevalence...

Nielsen, L. G., Rimvall, M. K., Clemmensen, L., Munkholm, A., Elberling, H., Olsen, E. M., Rask, C. U., Skovgaard, A. M. \& Jeppesen, P. (2019). The predictive validity of the Strengths and Difficulties Questionnaire in preschool age to identify mental disorders in preadolescence. PLOS ONE, 14(6): e0217707, 1-13. doi: 10.1371/journal. pone. 0217707

Ogundele, M. O. (2018). Behavioural and emotional disorders in childhood: A brief overview for paediatricians. World Journal of Clinical Pediatrics, 7(1), 9-26. doi: 10.5409/wjcp.v7.i1.9

Paulus, F. W., Backes, A., Sander, C. S., Weber, M., \& von Gontard, A. (2014). Anxiety Disorders and Behavioral Inhibition in Preschool Children: A Population-Based Study. Child Psychiatry \& Human Development, 46(1), 150-157. doi: 10.1007/s10578-014-0460-8

Pölkki, P. L., \& Vornanen, R. H. (2015). Role and Success of Finnish Early Childhood Education and Care in Supporting Child Welfare Clients: Perspectives from Parents and Professionals. Early Childhood Education Journal, 44(6), 581-594. doi:10.1007/s10643-015-0746-x

Poulou, M. S. (2015). Emotional and behavioural difficulties in preschool. Journal of Child and Family Studies, 24(2), 225-236. doi: https://doi.org/10.1007/s10826-013-9828-9

Prykanowski, D. A., Martinez, J. R., Reichow, B., Conroy, M. A., \& Huang, K. (2018). Brief Report: Measurement of Young Children's Engagement and Problem Behavior in Early Childhood Settings. Behavioral Disorders, 1-10. doi: 10.1177/0198742918779793

Reid, K., Littlefield, L., \& Hammond, S. W. (2008). Early intervention for preschoolers with behaviour problems: Preliminary findings for the Exploring Together Preschool Program. Australian e-Journal for the Advancement of Mental Health, 7(1), 15-29. doi: 10.5172/jamh.7.1.15

Rescorla, L., Ivanova, M. Y., Achenbach, T. M., Begovac, I., Chahed, M., Drugli, M. B., Emerich, D. R., Fung, D. S. S., Haider, M., Hansson, K., Hewitt, N., Jaimes, S., Larsson, B., Maggiolini, A., Marković, J., Mitrović, D., Moreira, P., Oliveira, J. T., Olsson, M., Ooi, Y. P., Petot, D., Pisa, C., Pomalima, R., Monzani, M., de Mattos Silvares, E. F., Szirovicza, L., Valverde, J., Anderssen Vera, L., Villa, M. C., Viola, L., Woo, B. S. C. \& Zhang, E. Y. (2012). International Epidemiology of Child and Adolescent Psychopathology II: Integration and Applications of Dimensional Findings From 44 Societies. Journal of the American Academy of Child \& Adolescent Psychiatry, 51(12), 1273-1283. doi: 10.1016/j.jaac.2012.09.012

Rogošić, S., Maskalan, A., \& Krznar, T. (2020). Preschool Teachers' Attitudes Towards Children's Gender Roles: The Effects Of Socio-Demographic Characteristics And Personal Experiences Of Gender Discrimination. Problems of Education in the 21st Century, 78(3), 410-422. doi: https://doi.org/10.33225/pec/20.78.410

Smith, B. J. \& Fox, L. (2003). Systems of service delivery: A synthesis of evidence relevant to young children at risk of or who have challenging behavior. Florida: Center for Evidence-based Practice: Young Children with Challenging Behavior.

Sutherland, K. S., Conroy, M. A., Algina, J., Ladwig, C., Jessee, G., \& Gyure, M. (2018). Reducing child problem behaviors and improving teacher-child interactions and relationships: A randomized controlled trial of BEST in CLASS. Early Childhood Research Quarterly, 42, 31-43. doi: 10.1016/j.ecresq.2017.08.001

Taggart, B., Sylva, K., Melhuish, E., Sammons, P. \& Siraj, I. (2015). Effective pre-school, primary and secondary education project. How pre-school influences children and young people's attainment and developmental outcomes over time. Preuzeto 10.05.2021. s https://assets.publishing.service.gov.uk/government/uploads/system/uploads/ attachment_data/file/455670/RB455_Effective_pre-school_primary_and_secondary_education_project.pdf.pdf

Taresh, M. S., Aniza Ahmad, N., Roslan, S., Ma'rof, A. M., \& Mohammed Zaid, S. (2020). Mainstream Preschool Teachers' Skills at Identifying and Referring Children with Autism Spectrum Disorder (ASD). International Journal of Environmental Research and Public Health, 17(12), 4284, 1-16. doi: 10.3390/ijerph17124284

Teekavanich, S., Chantaratin, S., Sirisakpanit, S. \& Tarugsa, J. (2017). Prevalence and Factors Related to Behavioral and Emotional Problems among Preschool Children in Bangkok, Thailand. Journal of the Medical Association of Thailand, 100(2), 175-182. 
Uğur, Ç., Yürümez, E. \& Yılmazer, Y. (2019). Emotional and behavioral problems in infants and preschool children: prevalence and sociodemographic risk factors. The European Research Journal, 5(1), 134-141. doi: 10.18621/ eurj.379887

Velki, T. \& Kuterovac Jagodić, G. (2015). Uloga strukturalnih i procesnih obiteljskih čimbenika u objašnjenju dječjega nasilničkog ponašanja prema vršnjacima. Ljetopis socijalnog rada, 22(2), 271-298. doi: https://doi.org/10.3935/ ljsr.v22i 2.22

Vlah, N., Mirosavljević, A. \& Katić, V. (2018). Nošenje odgajatelja predškolskih ustanova s rizičnim ponašanjima djece. Ljetopis socijalnog rada, 25(3), 369-401. doi: https://doi.org/10.3935/ljsr.v25i3.198

Zakon o predškolskom odgoju i obrazovanju. Narodne novine 10/97; 107/07; 94/13.

Živčić-Bećirević, I., Smojver-Ažić, S., \& Mišćenić, G. (2003). Problemi u ponašanju predškolske djece prema procjeni roditelja i odgojitelja. Psihologijske teme, 12(1), 63-76. 